\title{
PENGEMBANGAN MEDIA VIDEO ANIMASI UNTUK MATERI PEMBELAJARAN KARAKTER BERSAKSI DI SEKOLAH MINGGU
}

\author{
Denissa Alfiany Luhulima \\ Institut Agama Kristen Negeri Ambon \\ denissa6luhulima@gmail.com
}

\begin{abstract}
Sunday school is one of the non-formal education for children aged 1-15 years who are Christians in Indonesia, one of them in Maluku. The Sunday School in Maluku is one of them, under the Maluku Protestant Church (GPM) in the form of Sunday Schools and Tunas Pekabaran Injil (SM-TPI), and also Catechisms. The aim of the GPM Sunday School is to shape the character of GPM children in accordance with the character as written in the Bible; but to understand the Bible for children sometimes it is still difficult, because there are several styles of language and thoughts that are quite difficult for children to understand. Therefore, one way to ask children to understand Bible is by applying interesting medial. One of the media that can be used is videos. The types of videos made in this development are animated videos, and the material that is adapted to the Sunday school teaching materials of GPM level 3(9 Years Old), namely testifying character materials. This animated video was developed using the ASSURE research model. The result of the validation tests from material experts, media experts, design experts shows that animated videos are very useful and suitable to be used in the learning process in Sunday school. Based on the results of field tests of this animated video as well, it can help Sunday school children in understanding the material taught by the teacher, particularly the material of testifying characters.
\end{abstract}

Keywords: Sunday school, video, animation

\section{Pengantar}

Penggunaan media sebagai salah satu alat bantu dalam proses pembelajaran sudah-lah sangat disadari oleh banyak praktisi pendidikan. Munadi (2013) menyatakan bahwa media pembela-jaran adalah segala sesuatu yang dapat menyampaikan dan menyalur-kan pesan dari sumber secara terencana sehingga tercipta lingkungan belajar yang kondusif di mana pe-nerimaannya dapat melakukan pro-ses belajar secara efisien dan efektif. Media Video salah satu media yang sudah digunakan untuk membantu dalam pembelajaran. Ada berbagai macam jenis video salah satunya yaiu video animasi. Animasi sendiri merupakan suatu sequence gambar yang ditampilkan pada tenggang waktu tertentu sehingga terciptalah sebuah ilusi gambar bergerak. Secara sederhana animasi pada dasar-nya yaitu menggerakan objek agar tampak lebih dinamis dan menarik. Penggunaan animasi di dalam se-buah video pembelajaran mampu menarik perhatian, serta merangsang pemikiran pelajar yang lebih berkesan. Semuanya ini akan membantu dalam proses mengurangi beban kognitif pebelajar dalam menerima suatu materi pelajaran atau pesan yang ingin disampaikan oleh pem-belajar.

Greenberg dan Zanetis (2012) mengatakan bahwa menurut survei yang dilakukan oleh
Corporation for Public Broadcasting tentang penggunaan video dan televisi di North American schools $92 \%$ dari guru yang diwawancarai mengang-gap bahwa televisi dan video mem-bantu mereka untuk pembelajaran yang lebih efektif, sedangkan $88 \%$ menjawab bahwa teknologi memungkinkan mereka lebih kreatif. Selain itu hasil belajar dari $80 \%$ menunjukan hasil yang sangat posi-tif, akibat dari penggunaan teknologi video di dalam kelas.

Media video bukan saja dapat digunakan dalam proses pembelajaran pada pendidikan formal seperti sekolah dasar hingga perguruan tinggi, tetapi media video juga dapat digunakan dalam proses pembelajaran pada pendidikan non formal. Salah satu contoh pendidikan non formal yaitu pendidikan sekolah minggu. Media video digunaan pada sekolah minggu untuk membantu dalam pendalaman materi kepada anak sekolah minggu.

Sekolah Minggu merupakan salah satu pendidikan non formal untuk anak usia $1-15$ tahun yang beragama kristen di Indonesia. Se-kolah minggu pertama kali di didirikan oleh Robert Raikes, seorang wartawan dan anak pemilik perusahaan koran di Inggris yang pri-hatin dengan keadaan kaum muda gelandangan di kotanya 
Gloucester. Di Indonesia, Sekolah Minggu pun akhirnya berkembang dan masuk di wilayah Maluku.Wadah Sekolah Minggu di Maluku salah satunya berada di bawah Gereja Protestan Maluku (GPM) dalam bentuk Sekolah Minggu dan Tunas Peka-baran Injil (SM-TPI) dan Katekisasi. Pelaksanaan pendidikan dan pembi-naan bagi anak, remaja dan kate-kisasi GPM dikelompokkan sebagai berikut, 1) Jenjangb Anak batita usia 1-3 tahun, 2) Jenjang anak indria usia 4-6 tahun, 3) Jenjang anak kecil, usia 7-9 tahun, 4) Jenjang anak tanggung, 1012 tahun, 5) Jen-jang anak remaja berusia 13 sampai 15 tahun, dan 6) Katekisan GPM berusia 16 tahun ke atas.Tujuan SM-TPI dan Ketekisasi GPM adalah pembentukan karakter anak-anak GPM yang sesuai dengan karakter Yesus Kristus Tuhan yang tertulis di dalam Firman (Ulangan $6: 4-9$ ).

Jenjang Anak kecil merupakan salah satu jenjang pada sekolah minggu yang berisikan anakanak yang berusia antara 7 - 9 tahun. Pada jenjang anak kecil, anak dibagi lagi menjadi 3 sub jenjang yaitu anak umur 7 tahun berada pada sub jenjang anak kecil 1, anak umur 8 tahun berada pada sub jenjang anak kecil 2, dan anak yang berumur 9 tahun berada pada sub jenjang anak kecil 3. Di sekolah minggu Materi yang di ajarkan adalah materi yang bersumber dari Alkitab dan menurut Laheba (2007) memahami alkitab bagi anak-anak lebih sulit sebab ada beberapa gaya bahasa, pilihan kata yang cukup sulit dimengerti anak, untuk itulah cara terbaik untuk mengajak anak membaca dan me-mahami alkitab yaitu mengadakan kegiatan yang menarik bagi anak dengan memberikan bantuan visual dengan warna-warni yang menarik. Selain itu jenjang anak kecil sekarang ini, mereka tergolog dalam anak-anak Generasi Z. Menurut Miccrendel (2016) anak-anak Ge-nerasi Z adalah anak-anak yang lahir pada tahun 1995-2009 selain itu merupakan generasi global, sosial, visual, dan teknologi. Gaith (2010) dalam Mardina (n.d) mengemuka-kan bahwa gaya belajar untuk generasi $\mathrm{Z}$ juga bisa terpengaruh dengan adanya tenologi yang semakin modern, sehingga muncul anggapan bahwa cara belajar anak generasi $\mathrm{Z}$ sudah terbiasa dengan cepat, menciptakan koneksi secara acak, memprosesi infomasi visual secara dinamis, dan informasi yang diper-oleh bisa akurat dan bermanfaat. Dilihat dari faktor-faktor yang telah dijelaskan maka penggunaan video dapat dicoba sebagai salah satu me-dia pembelajaran di sekolah minggu. Penggunaan media video dapat diggunakan dalam proses pembe-lajaran di sekolah minggu karena media video dapat menarik perhatian anak karena penyajiannya dalam bentuk gambar dan suara, serta video dapat diputar berulang-ulang kali sehingga anak-anak dapat lebih memahami apa yang di sampaikan pengajar sekolah minggu. Selain itu gaya belajar anak di zaman sekarang ini yang lebih menyukai format audio-visual, maka penggunaan media video dapat dicobakan kepa-da anak-anak dalam membantu pro-ses pembelajaran.

Berdasarkan pada hal tersebut, maka peneliti ingin mengembang-kan salah satu media audio visual yaitu pengembangan media video animasi untuk materi pembelajaran karakter bersaksi di sekolah minggu yang materinya bersumber dari firman. Materi yang diajarkan pada video ini yaitu materi tentang pembelajaran karakter yang sesuai dengan bahan ajar yang digunakan di sekolah minggu khususnya pada jenjang anak kecil 3 yaitu bersaksi. Melalui materi ini anak dari kecil diajarkan untuk menjadi saksi Yesus Kristus Tuhan.

\section{Tinjauan Literatur Media Video Animasi}

Arsyad dalam Rusman dkk (2012) mengatakan bahwa video merupakan serangkaian gambar gerak yang disertai suara yang mem-bentuk satu kesatuan yang dirangkai menjadi sebuah alur, dengan pesanpesan didalamnya untuk ketercapaian tujuan pembelajaran yang disimpan dengan proses penyimpanan pada media pita atau disk. Pesan yang disajikan melalui video ini bisa bersifat fakta (kejadian/peristiwa penting, berita) maupun fiktif, bisa juga bersifat informatif, edukatif maupun instruksional.

Seiring dengan perkembangan zaman, media video ini pun akhir-nya mulai digunakan dalam dunia pendidikan pada proses pembe-lajaran. Menurut Riyana (2007) media video pembelajaran merupa-kan media yang menyajikan audio dan visual yang berisi pesan-pesan pembelajaran baik yang berisi kon-sep, prinsip, prosedur, teori aplikasi pengetahuan untuk membantu pe-mahaman terhadap suatu materi pembelajaran. Maka dari pengertian diatas maka dapat disimpulkan bahwa video merupakan suatu media audiovisual yang terdiri dari sekumpulan objek yang bergerak dengan memiliki audio yang sesuai. 
PENGEMBANGAN MEDIA VIDEO ANIMASI UNTUK MATERI PEMBELAJARAN KARAKTER BERSAKSI DI SEKOLAH MINGGU

Nugent dalam Smaldino,dkk (2008) mengatakan sudah banyak guru dalam pendidikan forrmal maupun non formal telah menggu-nakan video untuk memperkenalkan sebuah topik, untuk menyajikan konten, untuk memberikan perbaik-an, dan untuk membantu dalam pengayaan. Segmen video dapat digunakan dalam semua lingkungan pengajaran dengan kelas, kelompok-kelompok kecil dan individual pebelajar.

Penggunaan video sebagai media pembelajar semakin meluas seiring dengan kemajuan teknologi, hal ini dapat dilihat dari penyampaiannya dapat melalui Video Compact Disc (VCD) atau Digital Versatile Disc (DVD), disampaikan melalui televisi, bahkan sekarang disampaikan melalui internet yaitu video internet atau youtube. Menurut Isminiati (2012), sebagai sebuah media pembelajaran, maka karakteristik video yaitu (1) terdapat rumusan tujuan pembelajaran yang jelas, operasio-nal, dan terukur, (2) terdapat materi pembelajaran yang dikemas ke da-lam unit-unit atau kegiatan spesifik, (3) tersedia contoh dan ilustrasi yang mendukung kejelasan pemaparan materi, (4) video pembelajaran menggunakan penuturan (voice over) dengan bahasa yang sederhana dan mudah untuk dipahami, (5) bahasa yang digunakan lebih bersifat komunikatif, berusaha mengajak penonton lebih terlibat dalam materi yang disajikan, (6) kontekstual, yaitu materi yang disajikan terkait suasana atau konteks tugas dan lingkungan pebelajar, (7) terdapat instrument penilaian yang memung-kinkan pebelajar untuk melakukan self assesment, (8) terdapat instrument yang dapat digunakan menetapkan tingkat penguasaan materi untuk menetapkan kegiatan belajar selanjutnya, (9) tersedia rujukan atau pengayaan atau referensi yang mendukung materi yang diajarkan.

Animasi berasal dari bahasa latin yaitu "anima" yang berarti menghidupkan atau memberi nafas (Wright, 2005). Animasi merupakan salah satu media pembelajaran yang ber-basis komputer yang bertujuan untuk memaksimalkan efek visual dan memberikan interaksi berke-lanjutan sehingga pemahaman ten-tang pembelajaran dapat meningkat. Secara umum animasi dapat dibagi kedalam 3 kategori, yaitu 1). Traditional Animation, animasi tra-disional adalah kategori animasi yang sudah berumur sangat tua atau sangat lama. 2) Stop Motion Animation, adalah animasi yang menggunakan media perekam, mi-salnya kamera untuk menangkap pergerakan objek yang digerakkan sedikit demi sedikit. Cara kerja jenis animasi ini yaitu objek akan diatur untuk memperlihatkan pose tertentu dan kamera akan merekam pose objek tersebut. 3) Computer Grap-hic Animation, adalah jenis animasi yang keseluruhan prosesnya diker-jakan dengan media komputer. Ani-masi ini dapat berupa animasi 2D maupun animasi 3D. Sebagai media, animasi memiliki kemampuan untuk dapat memaparkan sesuatu yang rumit atau komplek untuk dijelaskan dengan hanya gambar dan kata-kata saja. Dengan kemampuan ini maka animasi dapat digunakan untuk menjelaskan suatu materi yang secara nyata tidak dapat terlihat oleh mata, dengan cara melakukan visua-lisasi maka materi yang dijelaskan dapat tergambarkan.

\section{Pembelajaran Karakter}

Mengajarkan karakter atau nilai merupakan fungsi pendidikan yang harus dijalankan oleh pendidikan formal, non-formal serta terintegrasi dalam setiap bagian dari kurikulum pendidikan (Watz, 2011). Lickona (2012) Dalam mengajarkan tentang karakter ada 3 bagian yang saling berhubungan yaitu moral knowing, moral feeeling, dan moral action. Karakter yang baik terdiri dari mengetahui hal yang baik, menginginkan hal yang baik, dan melakukan hal yang baik dalam cara berpikir, kebiasaan dalam hati dan kebiasaan dalam tindakan.

Karakter yang baik diperoleh melalui sebuah pembiasaan dan keteladan, sehingga karakter bukan saja hanya sebuah konsep tetapi perlu dikerjakan. Pebelajar membu-tuhkan panduan yang dapat membantu mereka agar dapar mempraktekkan karakter baik. Mengajarkan karakter akan berhasil bila disertai dengan media pembelajaran yang tepat dan diberikan sejak anak berusia dini, oleh karena itu dalam pengembangan video animasi untuk materi pembelajaran karakter ber-saksi ini penting untuk diperhatikan bahwa video pembelajaran ini dapat mengarahkan para pebelajar untuk mendapatkan informasi, serta motivasi untuk mendorong pebelajar mencapai tujuan pembelajaran khususnya untuk pembentukan karakter.

\section{Karakteristik Jenjang Anak Kecil 3}

Jenjang anak kecil 3 sekolah minggu merupakan kelas yang berisikan anak-anak berumur 9 tahun. Karakteristik anak pada jenjang anak kecil 3 sekolah 
minggu sama dengan karakteristik anak berumur 9 tahun pada umumnya.

Menurut Piaget (Suparno, 2001) dalam Suparno, anak pada umur 9 tahun merupakan anak yang perkembangan kognitif-nya masuk dalam tahap operasional konkret. Tahap ini dicirikan dengan perkembangan perkembangan sistem pemikiran yang didasarkan pada aturan-aturan tertentu yang logis. Pada tahap ini anak sudah mulai meninggkalan egosentrisnya dan dapat bermain dalam kelompok dengan aturan kelompok atau kerjasama. Anak dapat dimotivasi dengan mengerti hal-hal yang sistematis.

Menurut Sumiyatiningsih (Sumiyatiningsih,D. 2006) perkembangan moral/etika, perkembangan ego, dan perkembangan iman anak pada usia 9 tahun ini sebagai berikut : 1) Perkembangan moral/etika, anak mulai memperha-tikan kelompok dan menyesuaikan dengan norma-norma kelompok. Mereka mulai melakukakan relasi timbal balik dengan orang lain (we are good to each other). Motifnya adalah menjadi "anak lelaki yang baik dan anak perempuan yang manis" (to be a nice guy/girl) agar diterima oleh orang lain, menarik perhatian orang lain, dan mempunyai peran yang penting. Dalam dirinya mulai muncul kesanggupan menilai perbuatan dari motivasinya. 2) Perkembangan Ego, pada tahap ini anak mulai bergumul. Di satu sisi, dia ingin bersikap rajin, berkelakuan baik, dan berinisiatif. Namun, disisi lain, dia ingin mengalahkan rasa rendah diri. Anak mulai menyadari kompetensi, kemampuan, bakat, atau talentanya. Pada saatu ini, mereka sangat bersemangat untuk mengembangkan keterampilan, ingin mencapai sesuatu, dan bekerja dengan rajin sebagai suatu kesenangan atau untuk mendapatkan pengakuan. Mereka mulai senang mengerjakan hal-hal yang kom-pleks, senang membantu orang lain dan berminat untuk mengerjakan segala sesuatu yang berkaitan dengan belajar. Meskipun demikian, kadang-kadang mereka harus beru-saha melawan keinginan untu bersi-fat pasif, kehilangan ambisi, melawan keterlambatan, dan sulit ber-konsentrasi.3) Perkembangan Iman. Anak mengawali suatu taraf saat saat ia mengambil alih cerita atau kisah, kepercayaan, dan tradisi per-sekutuan tempat ia menjadi anggotanya, atau ambil bagian di dalamnya. Pada usia ini, anak mulai me-nempatkan diri dalam presepektif orang lain. Ia mulai memiliki world of view (pandangang dunia) yang didasarkan pada aspek resiprositas (asas memberi dan menerima). Anak juga mulai mengembangkan kesada-ran mengenai keadilan. Anak tertarik pada kisah-kisah atau cerita sederhana yang dapat dipahami. Pemahaman atau pengertian mereka masih bersifat harafiah (literal) dan sering kali, pandangannya terhadap yang baik dan yang jahat sangat sempit. Demikian juga pandangan-nya tentang keadilan. Imannya sering diekspresikan dalam ungka-pan : orang yang baik menerima berkat Tuhan, sementara orang yang jahat dihukum oleh Tuhan.

Karakteristik jenjang anak kecil 3 sekolah minggu di Gereja Protestan Maluku ini tidak jauh berbeda dengan karakter anak usia 9 tahun pada umumnya. Tetapi Sekolah Minggu di Greja Protestan Maluku memiliki sebuah tantangan besar, yaitu memperkenalkan nilai-nilai kristiani yang membentuk karakter dan perilaku yang baik dan benar sesuai ajaran firman Tuhan dengan melihat karakteristik anak zaman sekarang yang juga telah di-pengaruhi oleh teknologi dan media. Menurut Kristianto (2006), se-cara spiritual, anak-anak pada jenjang anak kecil 3 ini, mereka siap diajari ajaran keselamatan dengan lebih lengkap. Dengan bimbingan yang benar, mereka mampu menyelidiki dan mencari sendiri kebenaran-kebenaran yang dinyatakan oleh Alkitab. Mereka dapat membedakan antara yang benar dengan salah dan memiliki nurani yang lem-but. Mereka dapat mengambil keputusan untuk menerima Yesus Kristus Tuhan dan melayani Yesus Kristus Tuhan. Pengembangan video animasi untuk materi pembe-lajaran karakter bersaksi di sekolah minggu ini, memperhatian karak-teristik jenjang anak kecil 3 sekolah minggu tersebut..

\section{Metode}

Jenis penelitian yang dugunakan adalah $\mathrm{R} \& \mathrm{D}$ (Research and Development), sedangkan model pengembangan yang digunakan dalam penelitian ini yaitu menggunakan model ASSURE. Ada enam langkah dalam model pengembangan ini yaitu (1) Analyze Learners (Analisis Pebelajar), (2) States Objectives (Menyatakan Tujuan), (3) Select Methods, Media, and Materials (Memilih strategi, media, teknologi dan materi), (4)Utilize Media and Materials (Penggunakan media, teknologi, dan materi), (5) Require Learner Participation (Mengharus-kan partisipasi pebelajar), (6) Evaluate and Revise (Evaluasi dan perbaikan). 
PENGEMBANGAN MEDIA VIDEO ANIMASI UNTUK MATERI PEMBELAJARAN KARAKTER BERSAKSI DI SEKOLAH MINGGU

Setelah video dikembangkan maka video ini akan diujikan melalui 2 tahap yaitu (1) uji validasi, (2) uji produk. Uji validasi melibat 3 para ahli yaitu ahli media, ahli desain, dan ahli materi. Uji coba produk terdiri dari 3 tahap yaitu uji perorangan, uji kelompok kecil, dan uji lapangan. Uji coba produk dilakukan kepada jenjang anak kecil 3 pada sekolah minggu Jemaat GPM Klasis Kota Jemaat Bethania, dan Jemaat GPM Kota Jemaat Ebenhaezer. Uji coba perorangan terdiri dari 5 orang anak di jenjang anak kecil 3 Jemaat GPM Bethania, Uji coba kelompok kecil terdiri dari 12 orang anak di jenjang anak kecil 3 Jemaat GPM Bethania, dan uji coba lapangan terdiri dari 26 orang anak di jenjang anak kecil 3 Jemaat GPM Ebenhaezer.

Instrumen untuk mengumpulkan data dalam penelitian dan pengembangan ini berupa lembaran validasi, angket penilaian dan catatan lapangan. Lembaran validasi digu-nakan untuk mengumpulkan data dari ahli media, ahli desain, dan ahli materi. Angket penilaian digunakan untuk mengumpulkan data anak pada jenjang anak kecil 3 Selanjutnya, catatan lapangan digunakan untuk mencatat situasi lapangan saat uji coba penggunaan video animasi pembelajaran pada sekolah minggu. Teknik Analisis dalam penelitian ini dilakukan secara kualitatif dan kuantitatif. Teknik kualitatif dengan cara menganalisis data kualitatif berupa data verbal yang diperoleh dengan wawancara, catatan tertulis berupa komentar, saran, dan masukan yang tertulis pada angket penilaian. Teknik kuantitatif diguna-kan untuk menganalisis data kuantitatif yang diperoleh dari hasil vali-dasi ahli dan hasil test uji coba lapangan. Hasil uji coba produk ditabulasikan untuk mengklasifikasikan bagaimana video animasi pembelajaran dapat layak digunakan sebagai salah satu media pembelajaran di sekolah minggu.

\section{Rumus data per item :}

$P=\left(\frac{X}{X 1} X 100 \%\right)$

Keterangan :

$\mathrm{P}=$ Presentase $(\%)$

$\mathrm{X}=$ jumlah skor jawaban seluruh responden dalam satu item

$\mathrm{X} 1=$ jumlah skor ideal dalam satu item

Rumus untuk mengelola data secara keseluruhan item adalah :

$$
\mathrm{P}=\left(\frac{\Sigma X}{\Sigma \mathrm{X} 1} X 100 \%\right)
$$

Keterangan :

$\mathrm{P}=$ Presentase $(\%)$

$\sum \mathrm{X}=$ Jumlah keseluruhan skor jawaban responden

$\sum \mathrm{X} 1=$ Jumlah keseluruhan skor ideal

Setelah didapatkan hasil dari data yang diolah diatas hasil tersebut di konversikan dengan kriteria kelayakan sebagai berikut :

Tabel 1 Kriteria Kelayakan Pengembangan Video Pembelajaran Karakter Berbasis Animasi untuk Anak Sekolah Minggu

\begin{tabular}{|c|c|c|c|}
\hline No & Rentangan & Kriteria & Kualifikasi \\
\hline 1 & $81 \%-100 \%$ & Sangat Baik & Sangat Layak \\
\hline 2 & $61 \%-80 \%$ & Baik & Layak \\
\hline 3 & $41 \%-60 \%$ & Cukup & Cukup Layak \\
\hline 4 & $21 \%-40 \%$ & Kurang & Kurang Layak \\
\hline 5 & $0 \%-20 \%$ & $\begin{array}{c}\text { Sangat } \\
\text { Kurang }\end{array}$ & Tidak Layak \\
\hline
\end{tabular}

Sumber : (Riduwan, 2012)

\section{Hasil dan Pembahasan}

Hasil Penelitian dan pengem-bangan video animasi untuk materi pembelajaran karakter bersaksi di sekolah minggu yaitu :

\section{Analisis Pebelajar}

\section{A. Karakteristik Umum}

Karakteristik anak-anak se-kolah minggu jenjang anak kecil 3, anak-anak sudah bisa membedakan mana yang baik dan mana yang salah. Tetapi mereka masih cenderung memiliki sifat yang kurang baik, seperti kurang taat, suka membalas kejahatan dengan keja-hatan, suka bertengkar, suka mengucapkan kata-kata kotor atau makian, berbohong. Hal ini di pengaruhi juga oleh ling-kungan sekitar, dimana kehi-dupan orang Maluku cenderung keras dan kasar, terkadang se-buah masalah diselesaikan de-ngan cara pertengkaran yang akhirnya sikap ini juga berdam-pak pada anakanak. Sedangkan dalam proses pembelajaran anak-anak pada jenjang anak kecil 3, mereka cenderung tidak bisa diam, tetapi masih takut menjawab ketika ditanya atau takut ketika diminta untuk berbicara di depan, dan terkadang mereka masih sulit un-tuk berkonsentrasi. 


\section{B. Kemampuan Awal}

Anak-anak sekolah minggu jenjang anak kecil 3, mereka sudah mampu menyelediki dan mencari tentang kebenaran- kebenaran yang dinyatakan oleh Alkitab. Pengajaran untuk bisa menjadi saksi Yesus Kristus Tuhan, menyatakan kebenaran ditengah tantangan dan anca-man telah diajarkan, tidak ber-bohong sudah diajarkan di sekolah minggu melalui materi Kuasa Injil yang bersaksi . Karakter bersaksi merupakan karakter yang Yesus Kristus Tuhan berikan bagi setiap Anak yang memintanya.

\section{Gaya Belajar}

Tidak dapat dipungkiri bahwa gaya belajar anak zaman sekarang dipengaruhi oleh kemajuan teknologi. Hal ini pun terlihat pada gaya belajar anak - anak sekolah minggu. Jika para pengajar sekolah minggu mengajar tanpa menggunakan me-dia dan metodenya hanya sekedar ceramah, maka anak-anak sekolah minggu cenderung tidak fokus, bosan, dan akhirnya tidak memperhatikan pengajar sekolah minggu. Tetapi jika para pengajar sekolah mengajar dengan menggunakan media, serta metode mengajar yang digunakan bukan hanya sekedar ceramah, seperti contoh adanya permainan anak - anak akan cenderung fokus, tertarik, dan mudah memahami.

\section{Menyatakan Tujuan}

Materi ajar tentang bersaksi merupakan materi ajar sekolah minggu jenjang anak kecil 3 yang terdapat di dalam pokok sajian firman, dan ada di dalam 1 pokok bahasan yaitu po-kok bahasan kedua tentang kuasa injil Yesus Kristus Tuhan, dengan sub pokok bahasan yang terdapat pada poin 2.3. Kuasa injil yang bersaksi. Sehingga tujuan umum dan tujuan khusus materi bersaksi yaitu dapat dirumuskan sebagai berikut :

\section{Tabel 2 Tujuan Umum dan Tujuan khusus Materi Karakter Bersaksi}

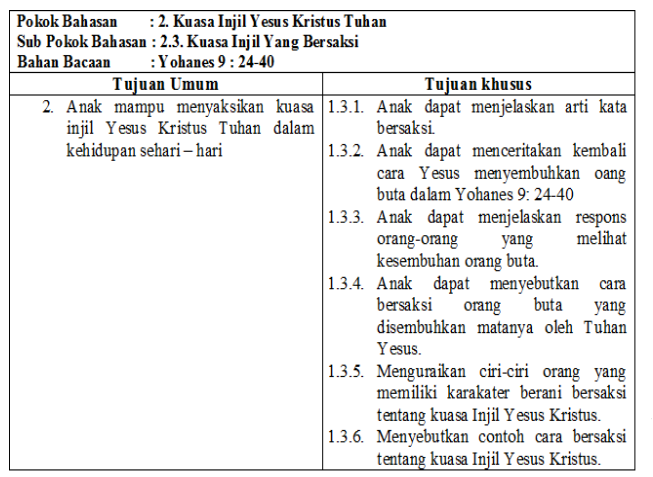

3. Memilih strategi, media, teknologi dan materi

\section{A. Strategi}

Strategi yang digunakan dalam pembelajaran dengan menggunakan media video animasi ini yaitu cooperative learning. Strategi ini digunakan agar anak-anak sekolah minggu dapat berkerja sama di dalam kelompok dan saling men-dorong untuk belajar.

Dalam pembelajaran dengan menggunakan media video ini, anak-anak sekolah minggu setelah menonton video yang ditayangkan maka anak-anak secara berkelompok akan melakukan aktifitas-aktfitas sesuai dengan petunjuk yang diberikan. Hal ini digunakan agar mendorong setiap individu anak-anak sekolah minggu agar saling membantu, saling menghargai memberikan kontribusi, dan saling memoti-vasi untuk keberhasilan kelompok, karena sifat-sifat seperti itu merupakan salah satu sifat yang dibutuhkan untuk dapat mengerti tentang materi karakter bersaksi

\section{B. Media}

Media yang di pilih dalam pembelajaran ini yaitu media audio-visual berupa video animasi. Media ini dipilih karena melihat karakteristik dan gaya belajar anak sekolah minggu GPM khususnya jenjang anak kecil 3 atau anak yang berusia 9 tahun. Mereka adalah anak-anak yang berkembang dengan teknologi yang sudah semakin canggih sehingga juga mem-pengaruhi gaya belajar mereka, tetapi di lain sisi mereka juga anak-anak yang terkadang masih sulit untuk berkonsentra-si, sehingga di perlukan sebuah media dalam membantu pembe-lajaran untuk membuat mereka dapat tertarik memperhatikan dan mengikuti pembelajaran. Selain media utama yaitu video animas yang digunakan ada juga beberapa media permainan yang digunakan untuk merefleksikan materi yang telah diajarkan melalui video tersebut.

\section{Materi}

Materi yang dipilih dalam video pembelajaran ini yaitu materi yang sesuai dengan bahan ajar yang digunakan di sekolah minggu khususnya materi jenjang anak kecil 3 yaitu materi tentang karakter khususnya karakter bersaksi. Materi ini dipilih juga 
PENGEMBANGAN MEDIA VIDEO ANIMASI UNTUK MATERI PEMBELAJARAN KARAKTER BERSAKSI DI SEKOLAH MINGGU

dengan melihat karakteristik anak-anak di Maluku yang kurang taat, terkadang suka membalas kejahatan dengan kejahatan, dan suka bertengkar, suka berbohong, dan suka mengucapkan kata-kata kotor atau makian. Melalui materi ini maka anak dari kecil diajarkan tentang bagaimana menjadi saksi Yesus Kristus Tuhan.

\section{Penggunakan media, teknologi, dan materi} A. Tinjauan Teknologi, media, dan material. Hal - Hal yang dilakukan pada bagian ini yaitu meliputi (1) membuat storyboard untuk alur cerita yang akan disampaikan pada video animas agar isi pada video sesuai dengan tujuan umum dan tujuan khusus yang telah dibuat. (2) Mendesain gambar animasi, dan narasi yang mudah untuk dimengerti oleh anak - anak dan menarik untuk ditampilkan di dalam video

Tabel 3

Sistematika isi video pembelajaran karakter bersaksi berbasis animasi untuk anak sekolah Minggu

\begin{tabular}{|c|c|c|c|}
\hline \multirow{2}{*}{ Seri } & \multicolumn{3}{|c|}{ Part } \\
\hline & Pertama (1) & Kedua (2) & Ketiga (3) \\
\hline \begin{tabular}{|l} 
Bersaksi \\
\end{tabular} & $\begin{array}{l}\text { Part pertama pada } \\
\text { seri bersaksi akan } \\
\text { menjelaskan tentang } \\
\text { - Pembukaan } \\
\text { materi karakter } \\
\text { bersaksi } \\
\text { - Cerita Alkitab } \\
\text { tentang "Y esus } \\
\text { Menyembuhkan } \\
\text { Orang Buta" }\end{array}$ & \begin{tabular}{|l} 
Part kedua pada seri \\
bersaksi akan \\
menjelaskan tentang \\
karakter bersaks \\
- Ciri-Ciri orang \\
yang ingin menjadi \\
saksi Y Ysus \\
- Alasan mengapa \\
anakh harus \\
memiliki karakter \\
bersaksi \\
- Sifat -sifat anak - \\
anak yang \\
memilikikarakter \\
bersaksi \\
Selain itu pada part ini \\
berisikan petunjuk \\
untrk anak - anak \\
mengerjakan aktifitas \\
yang terkait dengan \\
karakter bersaksi
\end{tabular} & $\begin{array}{l}\text { Part ketiga pada } \\
\text { seri bersaksi akan } \\
\text { berisikan tentang } \\
\text { - Pesan Tunan } \\
\text { terkait dengan } \\
\text { karakter } \\
\text { bersaksi } \\
\text { - Doa ang akan } \\
\text { dibacakan } \\
\text { bersama oleh } \\
\text { anak - anak } \\
\text { sekol ah } \\
\text { minggu } \\
\text { magu }\end{array}$ \\
\hline
\end{tabular}

B. Menyiapkan, teknologi, media, dan material

Hal-Hal yang dilakukan pada bagian ini yaitu (1) Mengga-bungkan semua gambar animasi, dan narasi sesuai story-board yang telah dibuat, sehing-ga menjadi sebuah video animasi (2) Membuat sebuah buku petunjuk pemanfaatan video animasi yang dapat dapat digu-nakan oleh para pengajar seko-lah minggu untuk mengetahui cara penggunaan media, dan apa saja langkah-langkah yang dilakukan ketika menyampai-kan materi (3) Membuat sebuah buku lembar kerja anak, agar anak dapat menulis hasil refleksi terhadap aktifitas yang dibuat disetiap materi.

\section{Menyiapkan Lingkungan}

Proses pembelajaran untuk setiap materi akan berlangsung di dalam kelas atau pada jenjang anak kecil 3. Di dalam kelas sudah tersedia LCD Proyektor, Layar LCD, laptop, dan speaker, sebagai alat pendukung untuk pemutaran video.

\section{Mempersiapkan Para Pebelajar}

Hal-hal yang dilakukan pada bagian ini yaitu (1) Para penga-jar sekolah minggu memper-kenalkan materi dan menyam-paikan tujuan pembelajaran yang akan di ajarkan pada saat itu. (2) Para pengajar sekolah minggu membentuk anak-anak menjadi beberapa kelompok dan membagikan buku lembar kerja anak yang akan digunakan ketika proses pembelajaran berlangsung pada awal.

\section{E. Menyediakan Pengalaman Belajar}

Hal-hal yang dilakukan pada bagian ini yaitu (1) Para pengajar sekolah minggu memberi-kan kegiatan apresepsi atau kegiatan awal (2) Pemberian aktifitas untuk anak-anak seko-lah minggu disetiap materi pe-ngajaran setelah menonton video (3) Anak-Anak berdiskusi dan menuliskan hasil refleksi untuk setiap akitiftas yang dila-kukan pada setiap materi penga-jaran (4) Pemberian umpan ba-lik dari pengajar sekolah ming-gu.

\section{Mengharuskan partisipasi pebelajar}

Hal yang dilakukan pada tahap ini yaitu, mengajak anak-anak sekolah untuk berpartisipasi melalui aktifitas secara berkelompok mau-pun individu. Aktifitas berkelompok yaitu (1) anak sekolah minggu dibagi menjadi beberapa kelompok (2) anak sekolah minggu sama- sama berdiskusi tentang makna per-mainan yang telah mereka mainkan dan dikaitkan dengan materi yang baru diajarkan dan video yang telah ditonton (3) anak sekolah minggu menuliskan hasil diskusi mereka kedalam lembar kerja anak (4) anak sekolah minggu menyampaikan hasil diskusi yang telah ditulis pada lembar kerja anak. Aktifitas individu yaitu anakanak diajak untuk sama- sama melakukan kegiatan awal atau apersepi yang diberikan oleh penga-suh yang berkaitan dengan materi yang akan di ajarkan. Selain itu juga anak-anak pun diminta untuk mengisi soal-soal latihan pada setiap materi yang diberikan oleh para pengajar sekolah minggu. 


\section{Evaluasi dan perbaikan.}

\section{A. Evaluasi Media dan Metode}

Berdasarkan angket yang telah diisi oleh para ahli yang terdiri dari ahli materi, ahli desain, dan ahli media, serta angket yang telah diisi oleh jenjang anak kecil 3 pada saatu uji perorangan, uji kelompok kecil, dan uji lapangan terkait video animasi untuk materi karakter bersaksi di sekolah minggu maka diperoleh hasil yaitu :

Tabel 4

\section{Evaluasi Para Ahli}

\begin{tabular}{|l|l|l|l|}
\hline \multicolumn{1}{|c|}{ Ahli } & \multicolumn{1}{|c|}{ Presentasi } & \multicolumn{1}{c|}{ Kriteria } & \multicolumn{1}{c|}{ Kualifikasi } \\
\hline Ahli Materi & $84,3 \%$ & Sangat Baik & Sangat Layak \\
\hline Ahli Desain & $89 \%$ & Sangat Baik & Sangat Layak \\
\hline Ahli Media & $97,3 \%$ & Sangat Baik & Sangat layak \\
\hline
\end{tabular}

Tabel 5

Jenjang anak kecil 3

\begin{tabular}{|l|l|l|l|}
\hline \multicolumn{1}{|c|}{ Uji Produk } & \multicolumn{1}{|c|}{ Presentasi } & \multicolumn{1}{c|}{ Kriteria } & \multicolumn{1}{c|}{ Kualifikasi } \\
\hline $\begin{array}{l}\text { Uji Perorangan } \\
\text { ( } 5 \text { Orang Anak) }\end{array}$ & $91,3 \%$ & Sangat Baik & Sangat Layak \\
\hline $\begin{array}{l}\text { Uji Kelompok } \\
\text { Kecil } \\
\text { (12 Orang Anak ) }\end{array}$ & $93,72 \%$ & Sangat Baik & Sangat Layak \\
\hline $\begin{array}{l}\text { Uji Lapangan } \\
\text { (26 Orang) }\end{array}$ & $96,92 \%$ & Sangat Baik & Sangat layak \\
\hline
\end{tabular}

Selain angket diberikan kepada jenjang anak kecil 3, peneliti juga memberikan angket kepada para pengajar sekolah minggu untuk menilai video pembelajaran yang dikembangkan. Angket ini diberikan kepada para pengajar sekolah minggu dilihat dari intensitas kehadiran pengasuh pada saat proses pembelajaran di sekolah ming-gu dengan menggunakan video pembelajaran yang dikembang-kan ini.

\section{Tabel 6}

Para Pengajar Sekolah Minggu

\begin{tabular}{|c|c|l|l|}
\hline Uji Produk & \multicolumn{1}{|c|}{ Presentasi } & \multicolumn{1}{|c|}{ Kriteria } & \multicolumn{1}{|c|}{ Kualifikasi } \\
\hline $\begin{array}{l}\text { Pengajar Sekolah } \\
\text { Minggu (8 Orang) }\end{array}$ & $95,25 \%$ & Sangat Baik & Sangat Layak \\
\hline
\end{tabular}

Hasil Presentasi pada setiap tabel diperoleh dari hasil pengisian angket dan kemudian di hitung menggunakan rumus untuk mengelola data secara keseluruhan item angket, setelah itu hasil presentasi di konversikan dengan kriteria kela-yakan. Rumus dan kriteria kela-yakan sesuai dengan yang sudah ditulis pada bagian metode penelitan pada jurnal ini.

Dilihat dari hasil yang diperoleh maka dapat disimpulkan bahwa video animasi untuk materi pembelajaran karakter bersaksi di sekolah minggu baik dan layak digunakan pada pro-ses pembelajaran di sekolah minggu khususnya jenjang anak kecil 3

\section{B. Evaluasi Penilaian penca-paian belajar jenjang anak kecil 3}

Pada proses pembelajaran di sekolah minggu Klasis Kota Ambon, tidak terdapat sebuah ketentuan nilai KKM untuk me-nilai hasil belajar anak apakah tuntas ataukah tidak seperti yang terdapat pada proses pembelajaran di sekolah formal. Karena pada dasarnya proses pembelajaran yang terjadi di sekolah minggu bertujuan untuk mendidik dan mendewasakan anak dan remaja GPM untuk memiliki karakter seperti yang diinginkan oleh Yesus Kristus Tuhan dan menanamkan ke-mampuan intelektual sesuai kebenaran firman Tuhan. Sehingga untuk mengukur hasil belajar anak dilihat melalui ke-tercapaian-ketercapaian tujuan khusus pada setiap pembe-lajaran melalui aktifitas-aktiftas yang diberikan oleh penga-jar sekolah minggu, seperti diskusi bersama, hasil tes lisan dan hasil tes tertulis yang dibuat oleh pengajar sekolah minggu, dan juga catatan orang tua anak-anak. Dari hal-hal tersebut ma-ka diperoleh hasil yaitu anak-anak memiliki nilai kognitif yang baik untuk setiap materi yang diajarkan dan anak mempraktekkan karakter bersaksi yang diajarkan di sekolah ming-gu, meskipun masih ada beberapa kenakalan-kenakalan yang mereka buat, mereka berusaha untuk selalu taat kepada orang tua, menghargai saudara bahkan orang lain, tidak bersungut-bersungut, mau menolong, beru-saha untuk tidak bertengkar dengan orang lain, berusaha untuk tidak mengucapkan katakata kotor atau makian, dan berusaha untuk jujur. Berdasarkan hasil-hasil tersebut penggunaan media video animasi untuk materi pembelajaran karakter bersaksi dapat disimpulkan bahwa layak digunakan untuk membantu dalam proses pembelajaran di sekolah khu-susnya kepada jenjang anak kecil 3 .

\section{C.Perbaikan}


PENGEMBANGAN MEDIA VIDEO ANIMASI UNTUK

Perbaikan video ini dila-kukan berdasarkan masukan dari ahli materi, ahli desain, dan ahli media. Berdasarkan uji coba para ahli, uji produk perorangan, kelompok kecil, dan uji lapangan dapat dikata-kan bahwa video animasi layak digunakan untuk membantu proses pembelajaran di sekolah minggu khususnya untuk jenjang anak kecil 3 pada materi karakter bersaksi.

Pada uji lapangan pendapat dari para pengajar sekolah minggu yaitu, video ini juga la-yak digunakan, baik dan mena-rik untuk anak-anak dalam belajar, membantu anak mema-hami materi, dan membantu pengajar sekolah minggu dalam memberikan materi.Pada bagian ini juga diuraikan apakah hipotesis yang diajukan telah terjawab sesuai hasil tabulasi data penelitian atau tidak sehingga dapat menjawab tujuan penelitian.

\section{Simpulan}

Berdasarkan pada pada hasil penelitian yang telah dilakukan maka dapat disimpulkan bahwa video animasi untuk materi pembelajaran karakter bersaksi di sekolah minggu sangat baik dan layak untuk membantu jenjang anak kecil 3 dalam memahami materi yang diajarkan. Tetapi ada beberapa aspek yang perlu dilihat lagi pada pengembangan video ini yaitu pertama video ini hendaknya dikembangkan lebih baik dan teliti lagi sehingga dapat memberikan hasil yang lebih baik lagi serta mengkaji lebih dalam pada saat pemilihan materi dan pemilihan software yang digunakan. Kedua, menambah gambar-gambar animasi yang lebih menarik lagi, serta musik pengiring ditambah dengan lagu - lagu sekolah minggu dan ketiga daya tarik dan kekonkritan dapat ditingkatkan dengan menggunakan foto asli atau gambar asli.

\section{Ucapan Terima Kasih}

Pada kesempatan ini, kami mengucapkan terima kasih kepada SMTPI Jemaat GPM Ebenhaizer di SKIP dan SMTPI Jemaat GPM Bethania di Batu Gajah yang telah bersedia menjadi objek penelitian bagi penulis. Terima kasih juga kepada Redaktur yang telah memberikan masukan yang berharga sehingga tulisan ini dapat disajikan di Jurnal Institutio, Terima kasih yang sama juga kami ucapkan kepada pengurus Jurnal Institutio yang telah memberi ruang diskusi

Semua bantuan dalam bentuk apapun yang diberikan kepada penulis, tidak dapat penulis balas
ARAN KARAKTER BERSAKSI DI SEKOLAH MINGGU satu persatu-satu, hanya doa semoga kita semua dapat senantiasa dalam lindungan Tuhan.

\section{Pustaka Acuan}

Degeng, I N. S. 2013. Ilmu Pembelajaran : Klasisfikasi Variabel Untuk Pengembangan Teori dan Penelitian. Bandung: Kalam Hidup.

Isminiati, C. 2010. Pengembangan dan Pemanfaatan Media Video Instruksional Untuk Meningkatkan Kualitas Pembelajaran. Majalah Ilmiah Pembelajaran Edisi Khusus 2012, (online), (http://staff.uny.ac.id/sites/default/files/pene litian/Dr.\%20Christina\%20Ismaniati,\%20M. Pd./Pengembangan\%20dan\%20pemanfaatan $\% 20$ media\%20video\%20instruksional $\% 20 \mathrm{u}$ ntuk\%20meningkatkan\%20kualitas\%20pem belajaran.pdf), diakses 26 Oktober 2016.

Laheba, N. 2007. Guruku Sahabatku : Panduan Mengajar Kreatif Untuk Guru Sekolah Minggu. Yogyakarta: Andi.

Lickona, T. 1991. Education For Character. Terjemahan J. A. Wamaungo. 2012. Jakarta: Bumi Aksara.

Lickona, T. 1993. The Return Of Character Education. Education Leadership Journal; November 1993. Volume 51(3): 8-11.

Lickona, T. 1999. Religion and Character Education. Phi Delta Kappan Journal; September 1999. Volume 81(1): 21-27.

Lickona, T. 2004. Character Matters. Terjemahan J. A. Wamaungo, J. A. Virtues. 2012. Jakarta: Bumi Aksara.

Marliani, R. 2016. Psikologi Perkembangan Anak \& Remaja. Bandung: Pustaka Setia.

Mccrindle.2016. Generation Z, (online), (http://generationz.com.au/), diakses 12 September 2016

Munadi, Y. 2013. Media Pembelajaran. Jakarta: Referensi.

Riduwan, M. 2012. Dasar - Dasar Statistik. Bandung: Alfabeta.

Riyana, C. 2007. Pedoman Pengembangan Media Video. Bandung: Univeristas Pendidikan Indonesia.

Rusman, K.D. \& Riyana, C. 2012. Pembelajaran Berbasisi Teknologi Informasi dan Komunikasi. Jakarta: PT. Raja Grafindo Persada. 


\section{Denissa Alfiany Luhulima}

Schmeck, R. R. 1988. Learning Strategies and Learning Style. New York: Springer.

Semiawan, C. R. 2008. Belajar dan Pembelajaran Prasekolah dan Sekolah Dasar. Indeks.

Seels, B.B. \& Richey, R.C. 1994. Teknologi Pembelajaran: Definisi dan Kawasannya. Jakarta. Kerjasama IPTPI LPTK UNJ.

Setyosari, P., \& Sihkabuden. 2005. Media Pembelajaran. Ma-lang: Elang Mas.

Sidjabat, B. 2011. Membangun Pribadi Unggul : Suatu Pen-dekatan Teologis terhadap pendidikan karakter. Yogya-karta: Andi.

Smaldino, S. E., Lowther, D. L., \& Russel, J. D. 2008. Instructional Technologi \& Media For Learning ( Kesembilan ed.). Terjemahan A. Rahman. 2011. Jakarta: Kencana.

Sumiyatiningsih, D. 2006. Mengajar Dengan Kreatif \& Menarik : Buku Pegangan Untuk Me-ngajar Pendidikan Agama Kristen. Yogyakarta: Andi.

Suparno, P. 2001. Teori Perkem-bangan Kognitif Jean Pia-get. Yogyakarta: Kanisius.

Susilana, R., \& Riyana, C.2009. Media Pembelajaran: Haki-kat, Pengembangan, Peman-faatan, dan Penilaian. Ban-dung: Wacana Prima.

Suyadi. 2013. Strategi Pembelaja-ran Pendidikan Karakter. Bandung: Remaja Rosdakar-ya.

Watz. M. 2011. An Historical Analysis of Character Edu-cation. Journal of Inquiry \& Action in Education. Volume 4 (2): 34 - 53.

Wright, J. A. 2005. Animation Wri-ting and Development : From Script Development to Pitch. USA: Focal Press.

Alkitab Terjemahan Baru. 2009. Jakarta: Lembaga Alkitab Indonesia

GPM, Tata Pelayanan Anak - Remaja dan Katekisasi Gereja Protestan Maluku tahun $2010-2015$ 